\title{
Melting and Exhumation of the upper structural levels of the Greater Himalaya Sequence and Makalu granite: constraints from thermobarometry, metamorphic modeling and U-Pb geochronology
}

\author{
Michael J Streule ${ }^{1 *}$, Michael P Searle ${ }^{1}$, Matthew SA Horstwood ${ }^{2}$ and David Waters ${ }^{2}$ \\ 1 Department of Earth Sciences, University of Oxford, Oxford OX1 3PR, UK \\ 2 NERC Isotope Geoscience Laboratory, Keyworth, Nottingham, NG12 5GG, UK \\ *For correspondence,email: michaels@earth.ox.ac.uk
}

The Makalu massif of Eastern Nepal displays a complex suite of Leucogranites and host sillimanite grade gneisses. These leucogranites are linked to the intrusions at the base of the Everest-Lhotse-Nuptse massif immediately to the west (Searle et al 2003) The Makalu intrusion is multiphase and forms the structurally highest foliationparallel sheets of leucogranite along the top of the Greater Himalayan Sequence on the Nepal-Tibet border. It is comprised of massive $\mathrm{Grt}+\mathrm{Tur}+\mathrm{Ms} \pm \mathrm{Bt}$ leucogranites that also occasionally contain large cordierite crystals. The abundance of cordierite in the upper granite sheet is unlike other granites in the Nepalese Himalaya. The cordierite bearing leucogranite overlies lower sheets of 'normal' Himalayan granites intruded into black sillimanite gneisses and is thought to be the most recent phase of magmatism. A few crosscutting feeder dykes mapped adjacent to the upper Barun glacier have channeled magma to the upper sheet. Petrology shows evidence for muscovite dehydration melting $\left(\sim<700^{\circ} \mathrm{C}\right)$ in the upper part of the Barun gneiss which is a likely mechanism by which to produce the Makalu granite melts. Host gneisses retain biotite and so melting temperatures did not exceed $800^{\circ} \mathrm{C}$ (White et al. 2001). Secondary cordierite rims around garnets in these gneisses and the presence of cordierite in leucogranites record the last low pressure phase of melting. We use these field and petrographic observations for the basis of detailed metamorphic modeling of decompression and geochronology work for the upper parts of the GHS.

P-T determinations (THERMOCALCv.3.30) detail peak sillimanite grade metamorphism at $713^{\circ} \mathrm{C}, 5.9 \mathrm{kbar}$, with a secondary cordierite overprint, only partially equilibrated in some samples, at $618^{\circ} \mathrm{C}, 2.1 \mathrm{kbar}$ (Figure 1). Thus rapid decompression of the GHS was associated with little temperature reduction. Monazite, zircon and xenotime geochronology directly links the timing of the low pressure cordierite event in the host rocks to those of the cordierite leucogranites; the main phase of leucogranite production and sillimanite grade metamorphism occurred from 25 to $18 \mathrm{Ma}$, whilst the most recent melt signature can be seen in the cordierite leucogranite and cordierite overprinted gneiss at $15.56 \pm 0.10 \mathrm{Ma}$ (Figure 1). Y mapping of monazites in cordierite overprinted rocks implies that the breakdown of garnet released $\mathrm{Y}$ into the metamorphic system to trigger monazite growth during this event.

This initial phase of high temperature induced melt production, followed by decompression induced melt production was modeled theoretically using THERMOCALC. Pseudosections, drawn with melt production accurately model the change in assemblage of the host metamorphic rocks, and the composition of the extracted melt. We therefore use this detailed study of geochronology and metamorphism to relate to current Channel Flow models of Himalayan orogenesis (e.g. Beaumont et al 2001, Law et al. 2006, Grujic 2006); In Nepal our data shows that melt weakening facilitated channel flow in the middle

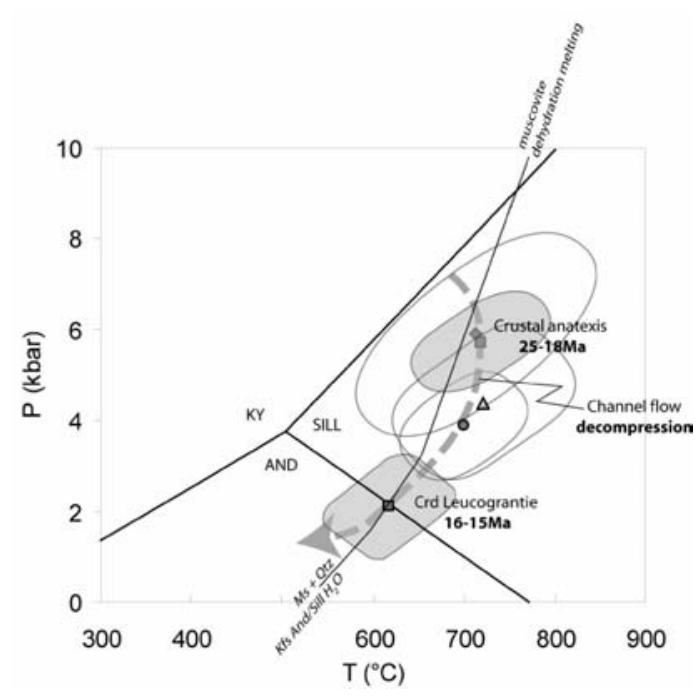

FIGURE 1. P-T-t data from Makalu: Crustal anatexis at 25-18Ma is correlated to peak Sillimanite grade metamorphism $(\diamond, \diamond, \square)$. Two samples are partially re-equilibrated to lower pressure $(\Delta, 0)$ whilst one sample details complete metamorphic overprinting ( $\square$ ) which is correlated to Cordierite granites at $16-15 \mathrm{Ma}$. The muscovite dehydration melting curve from White et al 2001.

crust. Timing of extrusion of the GHS corresponds with timing of melt production so we propose that channel flow occurred from 25-15 Ma.

References

White R, R Powell and T Holland. 2001. Calculation of partial melting equilibria in the system $\mathrm{Na}_{2} \mathrm{O}-\mathrm{CaO}-\mathrm{K}_{2} \mathrm{O}-\mathrm{FeO}-\mathrm{MgO}-\mathrm{Al}_{2} \mathrm{O}_{3} \mathrm{SiO}_{2}-$ $\mathrm{H}_{2} \mathrm{O}$ (NCKFMASH). Journal of Metamorphic Geology 19(2), 139-153

Searle, MP, RL Simpson, RD Law, RR Parrish and DJ Waters. 2003. The structural geometry, metamorphic and magmatic evolution of the Everest massif, High Himalaya of Nepal-South Tibet. Journal of the Geological Societ, 160(3), 345-366

Beaumont C, RA Jamieson, MH Nguyen and B Lee. 2001. Himalayan tectonics explained by extrusion of a low- viscosity crustal channel coupled to focused surface denudation. Nature 414, 739-742

Law RD, MP Searle and L Godin (eds). Channel Flow, Ductile Extrusion and Exhumation in Continental Collision Zones. Geological Society London, Special Publications 268

Grujic D. 2006. Channel flow and continental collision tectonics: an overview. In: Law RD, Searle MP and Godin L (eds). Channel Flow, Ductile Extrusion and Exhumation in Continental Collision Zones. Geological Society London, Special Publications 268: 25-37 